\title{
Excise taxes on sugar-sweetened beverages in Latin America and the Caribbean
}

\author{
Rosa Carolina Sandoval, ${ }^{1}$ Maxime Roche, ${ }^{1}$ Itziar Belausteguigoitia, ${ }^{2}$ Miriam Alvarado, ${ }^{3}$ Luis Galicia, ${ }^{4}$ \\ Fabio S. Gomes, ${ }^{1}$ and Guillermo Paraje ${ }^{5}$
}

Suggested citation Sandoval RC, Roche M, Belausteguigoitia I, Alvarado M, Galicia L, Gomes FS, et al. Excise taxes on sugar-sweetened beverages in Latin America and the Caribbean. Rev Panam Salud Publica. 2021;45:e21. https://doi.org/10.26633/RPSP.2021.21

ABSTRACT

Objective. To characterize the design of excise taxes on sugar-sweetened beverages (SSBs) in Latin America and the Caribbean and assess opportunities to increase their impact on SSB consumption and health.

Methods. A comprehensive search and review of the legislation in effect as of March 2019, collected through existing Pan American Health Organization and World Health Organization monitoring tools, secondary sources, and surveying ministries of finance. The analysis focused on the type of products taxed, and the structure and base of these excise taxes.

Results. Out of the 33 countries analyzed, 21 apply excise taxes on SSBs. Seven countries also apply excise taxes on bottled water and at least four include sugar-sweetened milk drinks. Ten of these excise taxes are ad valorem with some tax bases set early in the value chain, seven are amount-specific, and four have either a combined or mixed structure. Three countries apply excise taxes based on sugar concentration.

Conclusions. While the number of countries applying excise taxes on SSBs is promising, there is great heterogeneity in design in terms of structure, tax base, and products taxed. Existing excise taxes could be further leveraged to improve their impact on SSB consumption and health by including all categories of SSBs, excluding bottled water, and relying more on amount-specific taxes regularly adjusted for inflation and possibly based on sugar concentration. All countries would benefit from additional guidance. Future research should aim to address this gap.

Keywords

Noncommunicable diseases; nutrition policy; health economics; obesity; legislation as topic.

Across Latin America and the Caribbean, as in much of the world, the burden of noncommunicable diseases (NCDs) is high and growing. As of 2016, three out of four deaths in this region were due to NCDs, with $43 \%$ of NCD deaths among those under the age of 70 (1). The four main NCDs (cancers, diabetes mellitus, cardiovascular diseases, and chronic respiratory diseases) accounted for 2.15 million deaths, representing three-quarters of all NCD deaths (1). Worldwide, the cost of these four NCDs has been estimated to be US\$ 3.8 trillion in 2010, and is projected to increase to US\$ 7 trillion by $2030(2)$.

\footnotetext{
1 Pan American Health Organization, Washington D.C., United States of America $\square$ Maxime Roche, rochemax@paho.org

2 University of Lancaster, Lancaster, United Kingdom
}

The World Health Organization (WHO) identified a series of evidence-based, cost-effective solutions to prevent and control NCDs $(3,4)$. Included among these is the recommendation to reduce sugar consumption through effective taxation on sugar-sweetened beverages (SSBs) (3-5). SSBs are all types of non-alcoholic beverages containing free sugars; these include carbonated or non-carbonated soft drinks, fruit or vegetable juices and drinks, liquid and powder concentrates, flavored water, energy and sports drinks, ready-to-drink tea, ready-todrink coffee, and flavored milk drinks. They provide limited nutritional value, may lead to excessive caloric intake, and have 
been associated with negative health outcomes (6). They have been singled out as the largest driver of the obesity epidemic (7), and systematic reviews have demonstrated that consuming SSBs is linked with weight gain in children and adults (8), a higher risk of hypertension and coronary heart disease (9), and increased incidence of type 2 diabetes (10).

Latin America and the Caribbean has the highest absolute mortality related to SSB consumption in the world, with about 159 deaths per million adults (compared with 48 deaths per million adults globally), with $80 \%$ of these deaths associated to diabetes (11). Average daily SSB consumption per adult in Latin America and the Caribbean is the highest in the world, particularly in the Caribbean and Central America (1.93 and 1.61 average daily 8-ounce servings per adult, respectively, compared with 0.58 globally) (12). In addition, obesity levels are higher than in any other region in the world (13). Applying excise taxes on SSBs is one promising policy option to reduce SSB consumption and the burden of NCDs. Several evaluations of SSB excise taxes across Latin America and the Caribbean have demonstrated that these taxes are associated with reductions in sales and consumption of SSBs (14-17). For example, the 1 peso per liter excise tax introduced in Mexico in 2014 has been shown to have reduced SSB purchases by an average of $7.6 \%$ per year over the first two years following implementation (14). The two-tiered ad valorem excise tax in Chile has been associated with a reduction in household average monthly purchased volume of $3.4 \%$ among the SSBs with the highest sugar concentration (15). The ad valorem excise tax in Barbados has been associated with a $4.3 \%$ reduction in SSB sales over the first year (16). Finally, a simulation study found that in Mexico alone, the existing SSB excise tax is expected to prevent 86000 to 134000 cases of type 2 diabetes by 2030 and reduce the prevalence of obesity by $2.5 \%$, highlighting the potential of SSB excise taxes to contribute to NCD prevention efforts (17).

We focus our analysis on excise taxes in particular, as they have the greatest potential, from a health perspective, compared with other types of indirect taxes (e.g., at-cashier sales taxes or value-added taxes). Indeed, excise taxes allow policymakers to target and raise the price of selected products, making them relatively less affordable than other goods and services (18). An excise tax is applied on a selected good, imported or locally produced, and may be either amount-specific (based on beverage volume or sugar content; e.g., $\$ 0.10$ per liter) or ad valorem (based on a percentage of the value of the beverage; e.g., $10 \%$ of producer's price) (19). SSB excise taxes have been described as a triple win for governments, because they 1) improve population health, 2) generate tax revenue, and 3) have the potential to reduce long-term associated healthcare costs and productivity losses $(20,21)$.

While there are likely lessons learned from tobacco taxation that may also apply in the case of SSBs, best-practice guidance around SSB taxation is still under development. Most evaluations of excise taxes on SSBs are country-focused and concentrate on recently enacted taxes, implemented with an explicit health rationale. At the time of this analysis, it is not clear how many countries apply excise taxes on SSBs throughout Latin America and the Caribbean, or how these taxes vary in their design. It is important to comprehensively characterize the landscape of existing excise taxes on SSBs at country level, because of 1) the scope of the global NCD epidemic, 2) the recognition of SSB excise taxes as a cost-effective evidence-based intervention, and 3) the increased interest from policymakers around the world in amending or introducing such taxes.

The aims of this analysis are to provide the first exhaustive regionwide review of excise taxes on SSBs in Latin America and the Caribbean, to characterize the existing implementation of such taxes, and to assess opportunities to improve their impact on SSB consumption and health.

\section{MATERIALS AND METHODS}

We conducted a comprehensive search for legislation (including decrees, laws, excise tax acts, and statutory rules and orders) on excise taxes applied on non-alcoholic beverages in the 33 Latin American and Caribbean Member States of the Pan American Health Organization (PAHO), WHO Regional Office for the Americas. We reviewed legislation already collected through existing $\mathrm{PAHO} / \mathrm{WHO}$ monitoring tools-the WHO Global Nutrition Policy Review, the WHO Report on the Global Tobacco Epidemic, the WHO Global Information System on Alcohol and Health, and the PAHO NCD Country Capacity Survey-and conducted searches on websites of parliaments, ministries of finance, and legal databases. Finally, information on taxes applied on non-alcoholic beverages was solicited directly from officially nominated Ministry of Finance practitioners through a survey between March and December 2019 (hereafter called PAHO SSB tax survey). This survey was completed by 27 Latin American and Caribbean PAHO Member States (all except Argentina, the Bahamas, the Plurinational State of Bolivia, Costa Rica, Haiti, and Nicaragua).

\section{Criteria for inclusion}

We searched for excise taxes applied on non-alcoholic beverages in order to identify and analyze those applied on SSBs, whether or not excluding non-SSBs such as bottled water and artificially sweetened beverages. We included legislation listing the schedule of excise tax rates, as well as legislation describing the tax base upon which excise tax rates are applied. The data presented are based on legislation in effect as of 31 March 2019.

\section{Data extraction}

We extracted the following information from the legislation for each country: name, year of latest update, tax structure (ad valorem, amount-specific, mixed, or combined), and tax base. For ad valorem taxes, we assessed whether the tax base is defined early in the value chain (e.g., producer's price) or further down (e.g., retail price). For amount-specific taxes, we assessed whether the tax is automatically adjusted for inflation or other economic indicators.

In addition, we developed a simple set of indicators to capture heterogeneity in excise tax designs across countries. We evaluated if the tax follows a uniform or a tiered design; if sugar content is used as base for taxation; and whether it is applied to bottled water, in order to capture differentiations between SSBs and non-SSBs. Finally, we assessed whether the definition of taxable products includes sugar-sweetened milk drinks; energy drinks; and powders, concentrates, or syrups used to make SSBs by adding water or carbonated water, to evaluate whether each tax is applied to a broad scope of SSBs or includes loopholes, incentivizing undesirable substitutions and tax avoidance. 


\section{RESULTS}

We found that as of March 2019, 21 Latin American and Caribbean PAHO Member States impose excise taxes on SSBs, with a lower proportion in the Caribbean (6/13, information not available for Haiti) than in Latin America (15/19). Eleven countries do not have an excise tax on SSBs, including Colombia, Cuba, the Dominican Republic, the Bolivarian Republic of Venezuela, and the majority of Caribbean countries (Table 1).

TABLE 1. Summary of excise taxes on sugar-sweetened beverages in Latin America and the Caribbean (based on legislation in effect as of 31 March 2019)

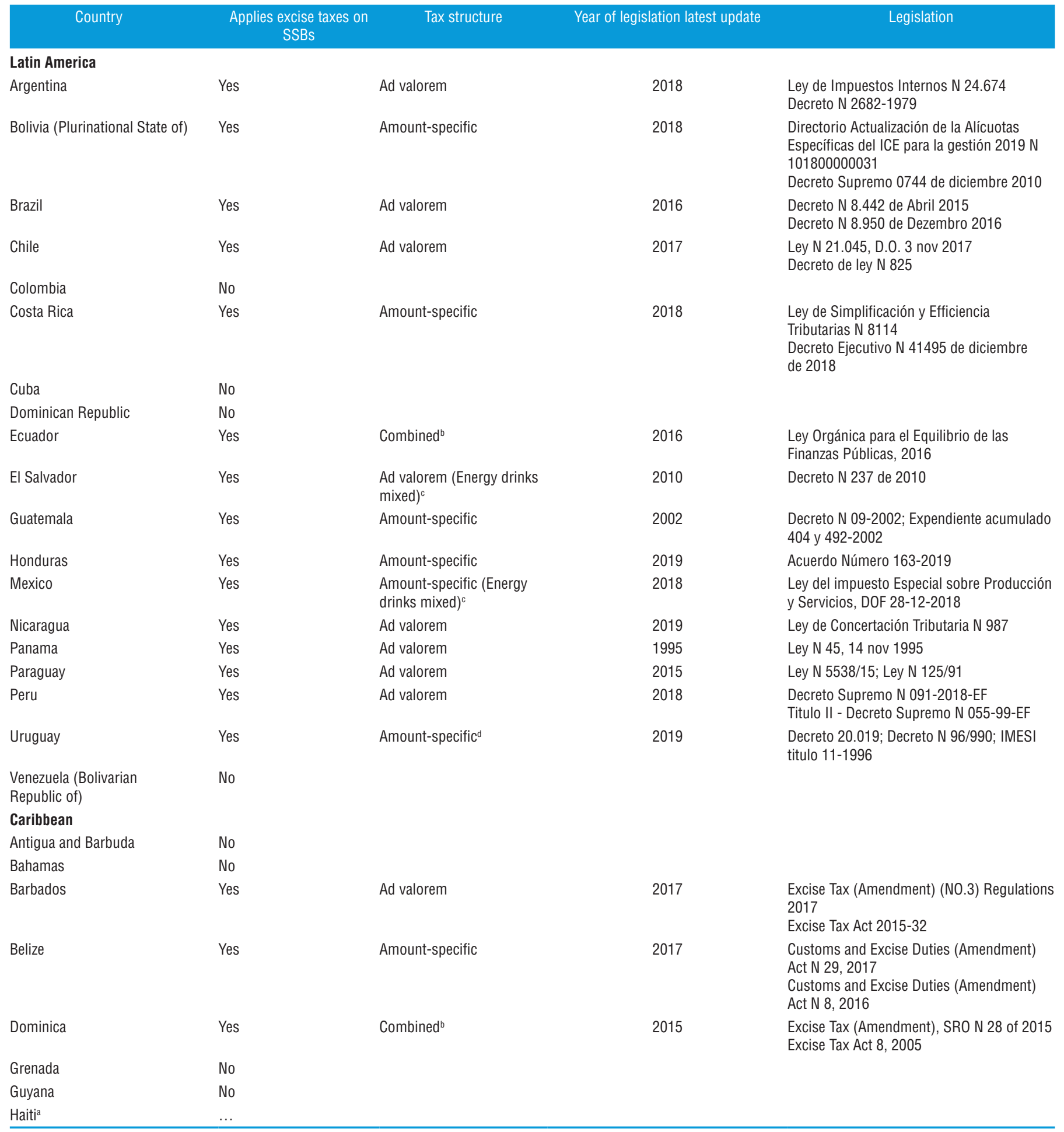




\section{TABLE 1. (Continued)}

\begin{tabular}{|c|c|c|c|c|}
\hline Country & $\begin{array}{l}\text { Applies excise taxes on } \\
\text { SSBs }\end{array}$ & Tax structure & Year of legislation latest update & Legislation \\
\hline Jamaica & No & & & \\
\hline Saint Kitts and Nevis & Yes & Ad valorem & 2010 & Excise Tax Act No. 4, 2010 \\
\hline Saint Lucia & No & & & \\
\hline $\begin{array}{l}\text { Saint Vincent and the } \\
\text { Grenadines }\end{array}$ & Yes & Ad valorem & 2009 & Excise Tax Act Chapter 430 SR0 2 \\
\hline Suriname & Yes & Amount-specific & 2006 & $\begin{array}{l}\text { S.B. } 2006 \text { no. } 27 \text { wijz. Wet Accijns } \\
\text { Alcoholvrije Dranken }\end{array}$ \\
\hline Trinidad and Tobago & No & & & \\
\hline \multicolumn{5}{|c|}{$\begin{array}{l}\text {..: information not available } \\
\text { a Haiti: The country did not participate in PAHO SSB tax survey in 2019. From our search for legislation, we found a law from 1971, "Loi sur le Droit d'Accise du } 21 \text { Octobre } 1971, \text { " imposing an amount-specific excise tax both on imported } \\
\text { and locally produced carbonated drinks. However, a later World Trade Organization report states that as of June } 2015 \text {, the excise tax had a different structure for imported (amount-specific) and locally produced (ad valorem) carbonated } \\
\text { drinks, which could constitute a violation of national treatment (22). We did not find more recent information or legislation regarding this tax. Due to the potential discriminatory nature of the tax between imported and locally produced } \\
\text { beverages and the lack of information, we decided not to include this tax in our analysis. } \\
\text { b Combined: At least one type of non-alcoholic beverage is taxed by an ad valorem excise tax and at least one other type is taxed by an amount-specific excise tax. No beverage type is taxed by both. } \\
\text { c Mixed: At least one type of non-alcoholic beverage is taxed by both an ad valorem excise tax and an amount-specific excise tax. In El Salvador and Mexico, only energy drinks are subject to a mixed excise tax system. } \\
\text { d Uruguay: The excise tax on SSBs is structured as an ad valorem tax applied on fixed tax base amounts-"precios fictos"- per volume varying per beverage type, effectively operating as an amount-specific tax and classified as such in } \\
\text { this analysis. } \\
\text { Source: Prepared by the authors from the study data. }\end{array}$} \\
\hline
\end{tabular}

\section{Taxable products}

Countries that impose excise taxes on SSBs define taxable products in different ways. Every Caribbean country and some Latin American countries (mostly in Central America) use harmonized tariff codes-an international standardized nomenclature to classify traded products-to define taxable products, although the range of tariff codes included is wide. Importantly, while some harmonized tariff codes are defined based on added sugars (e.g., 2202: "Waters, including mineral waters and aerated waters, containing added sugar or other sweetening matter"), others are not (23), and countries may have to develop more detailed country-specific codes to differentiate SSBs. Most other Latin American countries have developed definitions of taxable products based on beverage type.

Of all countries imposing excise taxes on SSBs, seven apply them to bottled water as well. At least 14 countries include one or more of the following products in their list of taxable products: powders, concentrates, or syrups used to make SSBs by adding water or carbonated water. All countries imposing excise taxes on SSBs apply such taxes on energy drinks. Finally, at least four countries (Barbados, Panama, Peru, and Saint Vincent and the Grenadines) apply excise taxes on sugar-sweetened milk drinks (Table 2).

\section{Tax structure}

Existing excise taxes on SSBs rely on a diverse range of tax structures. Ten countries exclusively use ad valorem taxes and seven exclusively use amount-specific taxes. Dominica and Ecuador use a combined excise tax structure. Dominica applies an ad valorem tax on SSBs except for carbonated SSBs, which are subject to an amount-specific tax. Ecuador imposes an amount-specific tax on SSBs with a sugar concentration above a specified threshold, and an ad valorem tax on SSBs below this threshold. All energy drinks (regardless of their sugar concentration) are taxed by the ad valorem tax. Finally, El Salvador and Mexico use a mixed excise tax structure on energy drinks. Mexico primarily uses an amount-specific tax and applies an additional ad valorem tax on energy drinks, while El Salvador primarily uses an ad valorem tax and applies an additional amount-specific tax on energy drinks (Table 1).
In five countries (the Plurinational State of Bolivia, Costa Rica, Ecuador, Honduras, and Mexico), out of the 11 including an amount-specific component, the legislation stipulates the periodic automatic adjustment of their amount-specific excise tax (Table 2).

Eleven excise taxes on SSBs in the region apply multiple tax rates (tiered design), as opposed to applying a single tax rate to all SSBs subject to the excise tax (uniform design). Tiered rates are most commonly defined by beverage type or harmonized tariff code. Other examples include tiered rates defined by sugar concentration thresholds (e.g., Peru and Chile), by a combination of beverage type and sugar content (e.g., Ecuador), or by a combination of beverage type and fruit juice concentration (e.g., Argentina). Ten countries impose uniform excise taxes (Table 2).

\section{Tax base}

For ad valorem excise taxes, the tax base is defined as the value of the taxed product, which may be assessed at different stages of the value chain. When the tax base for locally produced beverages is fixed early in the value chain, such as the producer's price, as is the case in five countries (Barbados, Brazil, Dominica, Mexico, and Paraguay), ad valorem tax rates are applied to a smaller value, diminishing the impact of the tax on final retail prices. The nine other countries including an ad valorem component use a tax base for locally produced beverages defined later in the value chain, closer to the final retail price (Table 2). For imported beverages, countries applying ad valorem excise taxes use the Cost, Insurance, and Freight (CIF) value and import and custom duties, when applicable, as tax base. The CIF value is used in most countries as the base for import duties and is defined as the value of the unloaded consignment that includes the cost of the product itself, insurance, and transport and unloading. Such tax base, set early in the value chain, diminishes the impact of the tax on final retail prices.

For amount-specific excise taxes, the tax base may be defined by beverage volume or sugar content. Almost all countries with an amount-specific component use beverage volume as tax base. Only Ecuador uses sugar content as tax base for its amount-specific excise tax of US\$ 0.18 per 100 grams of sugars for beverages with more than 25 grams of sugars per liter 
TABLE 2. Information on the design of excise taxes on sugar-sweetened beverages in Latin America and the Caribbean (based on legislation in effect as of 31 March 2019)

\begin{tabular}{|c|c|c|c|c|c|c|c|c|}
\hline $\begin{array}{c}\text { Country } \\
\text { applying excise taxes } \\
\text { on SSBs }\end{array}$ & $\begin{array}{l}\text { Applies on } \\
\text { bottled water }\end{array}$ & $\begin{array}{c}\text { Applies on } \\
\text { powders, } \\
\text { concentrates, or } \\
\text { syrups }^{\text {e }}\end{array}$ & $\begin{array}{l}\text { Applies on energy } \\
\text { drinks }\end{array}$ & $\begin{array}{c}\text { Applies on } \\
\text { sugar-sweetened } \\
\text { milk drinks } \\
\text { (harmonized tariff }^{\text {code: } 040299)^{\mathrm{e}}}\end{array}$ & $\begin{array}{c}\text { Ad valorem tax base } \\
\text { for locally produced } \\
\text { beverages }\end{array}$ & $\begin{array}{c}\text { Automatic } \\
\text { adjustment of } \\
\text { amount-specific } \\
\text { tax for inflation or } \\
\text { other economic } \\
\text { indicators }^{e}\end{array}$ & $\begin{array}{l}\text { Excise tax based } \\
\text { on sugar content }\end{array}$ & $\begin{array}{l}\text { Uniform tax } \\
\text { rate (No }= \\
\text { tiered) }\end{array}$ \\
\hline
\end{tabular}

\section{Ad valorem excise tax}

\section{structure}

Argentina

Barbados

Yes

Yes

Brazil

Chile

No

$\mathrm{No}^{\mathrm{d}}$

No

Nicaragua

Panama

Paraguay

Peru

Yes

No

No

No

Saint Kitts and Nevis No

Saint Vincent and the No

Grenadines

\section{Amount-specific \\ excise tax \\ structure}

Belize

Yes

Bolivia (Plurinational No

State of)

Costa Rica

Guatemala

Honduras

Suriname

Uruguay $^{\mathrm{a}}$

Yes
Yes
No
Yes
Yes

Yes

Yes
Yes
Yes

Yes
Yes
No
No

$\begin{array}{ll}\text { Yes } & \ldots \\ \text { Yes } & \text { Yes } \\ \text { Yes } & \text { No } \\ \text { Yes } & \text { No } \\ & \\ \text { Yes } & \ldots \\ \text { Yes } & \text { Yes } \\ \text { Yes } & \text { No } \\ \text { Yes } & \text { Yes }\end{array}$

$\begin{array}{lll}\text { No } & \text { Yes } & \text { No } \\ \text { No } & \text { Yes } & \text { Yes }\end{array}$

excl

Retail price
excluding VAT
Producer price

Producer price

Retail price

excluding VAT

Retail price

Retail price

Producer price

Retail price

excluding VAT

and excise

Retail price

excluding VAT

Retail price

excluding VAT

NA

NA

NA

NA

NA

NA

NA

NA

NA

NA

No

Yes

No

No

Yes

NA

Yes

No

No

NA

NA

NA

Yes

No

No

No

Yes

No

No ${ }^{9}$

No Yes

No Yes

No No

Combined excise

tax structure ${ }^{\mathrm{b}}$

\begin{tabular}{|c|c|c|c|c|c|c|c|c|}
\hline Dominica & No & Yes & Yes & No & Producer price & No & No & No \\
\hline Ecuador & No & Yes & Yes & No & $\begin{array}{l}\text { Retail price } \\
\text { excluding VAT } \\
\text { and excise }\end{array}$ & Yes & Yes & No \\
\hline
\end{tabular}

\section{Mixed excise tax}

\section{structure ${ }^{\mathrm{c}}$}

El Salvador

No

Yes

Yes

No

Retail price

$\mathrm{No}{ }^{\mathrm{h}}$

No

No

excluding VAT

base "precios

fictos"

Mexico

No

Yes

Yes

No

and excise

... : information not available

NA: not applicable
VAT: value-added tax

Uruguay: The excise tax on SSBs is structured as an ad valorem tax applied on fixed tax base amounts—-precios fictos"-per volume varying per beverage type, effectively operating as an amount-specific tax and classified as such in

${ }^{\circ}$ Combined: At least one type of non-alcoholic beverage is taxed by an ad valorem excise tax and at least one other type is taxed by an amount-specific excise tax. No beverage type is taxed by both

Mixed: At least one type of non-alcoholic beverage is taxed by both an ad valorem excise tax and an amount-specific excise tax. In El Salvador and Mexico, only energy drinks are subject to a mixed excise tax structure.

Brazil: Only natural mineral waters are exempted from excise taxes.

"Information only available for the countries which answered PAHO SSB tax survey. For Argentina, the Plurinational State of Bolivia, Costa Rica, and Nicaragua, in some cases, the information could still be extracted from the legislation.

'Mexico: The ad valorem component applies only to energy drinks.

"Uruguay: The fixed tax base amounts- "precios fictos"-are usually adjusted annually; however, it is not mandated by law.

.

Chile and Peru. Tered design wich diflerent ad valorem tax rates defined by sugar concentration thresholds.

Nicaragua: The ad valorem tax rate is uniform for sugar-sweetened beverages, but a lower rate applies to mineral water. 
(except for energy drinks). In addition, Chile and Peru both utilize a tiered ad valorem excise tax design with different tax rates defined by sugar concentration thresholds (Table 2).

\section{DISCUSSION}

The majority of countries across Latin America and the Caribbean impose excise taxes on SSBs. Some of these taxes, however, have not been updated for over a decade, and many are not optimized to achieve health goals.

\section{Key considerations in the design of SSB excise taxes}

Drawing on tobacco taxation best practice, we identify key considerations for the various excise tax structures observed. Ad valorem excise taxes on tobacco products have been shown to widen the gap between the price of the cheapest and most expensive products, incentivizing consumers to switch to cheaper brands and undermining the potential health benefits of the tax (18). Emerging evidence suggests that ad valorem excise taxes on SSBs may have a similar effect (16). In addition, ad valorem excise taxes applied on a tax base set early in the value chain, such as the producer's price for locally produced beverages and the CIF value for imported beverages, have a lower impact on the final retail price than if applied on a tax base set later in the value chain, such as the retail price. On the other hand, amount-specific excise taxes apply on the same tax base for locally produced and imported beverages. They also reduce the incentives to switch to less expensive brands. Nevertheless, the real value of amount-specific excise taxes and their effectiveness in reducing consumption tend to diminish over time if they are not regularly adjusted to account for inflation and also, ideally, for income growth (18).

According to $\mathrm{WHO}$, excise taxes calculated based on sugar content can have a greater impact. Indeed, they create a tax burden differential between options based on sugar content within a product category and could incentivize consumers to switch to beverages with lower sugar content while simultaneously encouraging producers to reformulate their beverages (5).

Following the same rationale, from a health point of view, excise taxes should not be applied on bottled water. This undermines the ability of these taxes to generate a price differential between SSBs and non-SSBs and does not incentivize consumers to switch from consuming SSBs to a healthier alternative. It demonstrates that, in some countries, excise taxes on SSBs have been implemented to increase revenues, without considering them as a health policy instrument.

Finally, the list of taxable products should incorporate all types of SSBs, including sugar-sweetened milk drinks and powders, concentrates, or syrups used to make SSBs by adding water or carbonated water, in order to prevent undesirable substitutions of taxed SSBs for untaxed SSBs. Simplicity and transparency in the tax structure and the definition of taxable products reduce opportunities for tax avoidance.

\section{Opportunities to focus on health}

In light of the aforementioned considerations, existing excise taxes could be amended to improve their effectiveness in reducing SSB consumption, by relying more on amount-specific taxes, taxing based on sugar content, increasing tax rates, excluding bottled water from the list of taxable products, and closing loopholes incentivizing undesirable substitutions by explicitly including all categories of SSBs-sugar-sweetened carbonates, fruit-flavored drinks, fruit juices, sports and energy drinks, vitamin water drinks, sweetened iced teas and lemonades, sugar-sweetened milk drinks and yogurts, as well as powders, concentrates, or syrups used to make SSBs by adding water or carbonated water-in the list of taxable products.

Among the countries that do not impose excise taxes on SSBs, there is an opportunity for the public health community to advocate for their introduction and to ensure that they are designed to optimize health outcomes from the outset.

\section{Need for SSB taxation best practice}

There is great heterogeneity across existing excise taxes on SSBs and limited guidance around SSB taxation best practice in comparison with guidance for tobacco and alcohol taxation (18, 24). There is a clear need to further develop empirically based best practice for effective SSB excise tax design. Future research should aim to evaluate the impact that different excise tax designs have on prices, consumption, tax revenue, and health outcomes, and the extent to which different designs could be associated with unintended consequences.

\section{Need for systematic monitoring of SSB taxation}

It is necessary to develop periodic and standardized monitoring systems to capture changes in levels of taxation applied to SSBs over time and allow comparisons between countries. For this purpose, building on WHO experience with the monitoring of tobacco taxation, PAHO is currently working on the development of a standardized tax share indicator to calculate the share of total indirect taxes (including value-added taxes, excise taxes, and import and customs duties) in the retail price of SSBs in Latin America and the Caribbean (25).

\section{Limitations of the analysis}

In our analysis, we do not report statutory excise tax rates from the legislation. Indeed, comparisons between countries can be misleading unless differences in tax structure, tax base, price, sugar content, and beverage volume are taken into account. While we did not focus on statutory excise tax rates, it is important to note that these rates need to be sufficiently high to effectively disincentivize consumers from purchasing SSBs $(5,20,26)$.

While we analyzed if existing excise taxes apply particularly on some categories of non-alcoholic beverages, we did not assess the taxation of fruit-flavored drinks, fruit juices, or sports drinks. Fruit juices and sports drinks were not part of the beverages for which PAHO SSB tax survey collected tax information. On the other hand, while tax information on fruit-flavored drinks was collected by PAHO SSB tax survey, the information was difficult to verify in the legislation due to the broad definition of harmonized tariff code 2009, which includes fruit juices "whether or not containing added sugar or other sweetening matter" (23).

Finally, data presented in our analysis are based on legislation that was in effect as of 31 March 2019. Legislation that 
could have been replaced, amended, or repealed since this cutoff date are not analyzed to maintain comparability of data at the same point in time in all countries. Since this cutoff date, we did not identify any introduction of new excise taxes on SSBs in Latin America and the Caribbean.

\section{Conclusion}

As of March 2019, there are 21 countries applying excise taxes on SSBs across Latin America and the Caribbean. While this is promising, most of these taxes could be further leveraged to improve their impact on SSB consumption and health. This represents an opportunity to propose amendments to existing excise taxes and advocate for the introduction of such taxes in the countries that do not currently impose them.

There is a high diversity in the design of existing excise taxes on SSBs. All countries would benefit from additional guidance around how to introduce or amend excise taxes on SSBs to optimize health gains. Given the current and projected global burden of NCDs, it will be important to closely monitor the use of this effective population-level policy and to maximize its health potential.
Author contributions. RCS conceptualized the study. All authors collected the data. MR, IB, MA, LG, and GP analyzed the data and interpreted the results with input from all authors. MR, IB, and MA drafted the manuscript and all authors critically revised it. All authors reviewed and approved the final version.

Acknowledgment. We would like to thank and acknowledge the valuable contributions of the Department of Noncommunicable Diseases and Mental Health at PAHO, especially Anselm Hennis, Adriana Blanco, Ruben Grajeda, Maristela Monteiro, Elisa Prieto, Alicia Nicholls, Patty Welch, Alejandro Alvarez, and Steven Constantinou, and the O'Neill Institute for National and Global Health Law at Georgetown University. Special thanks to all Latin American and Caribbean ministry of finance officials who participated in the survey. We also thank and acknowledge the support from the Global Health Advocacy Incubator and funding from Bloomberg Philanthropies.

Conflict of interest. None declared.

Disclaimer. Authors hold sole responsibility for the views expressed in the manuscript, which may not necessarily reflect the opinion or policy of the RPSP/PAJPH and/or PAHO.

\section{REFERENCES}

1. Pan American Health Organization. Noncommunicable diseases in the Region of the Americas: facts and figures [Internet]. Washington, DC: PAHO; 2019 [cited 2020 Mar 23]. Available from: https:// iris.paho.org/handle/10665.2/51483

2. Bloom D, Cafiero E, Jané-Llopis E, Abrahams-Gessel S, Bloom L, Fathima S, et al. The Global Economic Burden of Non-communicable Diseases [Internet]. Geneva: World Economic Forum; 2011 [cited 2019 Apr 18]. Available from: http://www3.weforum.org/docs/ WEF_Harvard_HE_GlobalEconomicBurdenNonCommunicableDiseases_2011.pdf

3. World Health Organization. Tackling NCDs: 'Best buys' and other recommended interventions for the prevention and control of noncommunicable diseases [Internet]. Geneva: WHO; 2017 [cited 2019 Apr 18]. Available from: https://apps.who.int/iris/ handle/10665/259232

4. World Health Organization. Technical Annex: Updated Appendix 3 of the WHO Global NCD Action Plan 2013-2020 [Internet]. Geneva: WHO; 2017 [cited 2019 Mar 4]. Available from: https:/ /www.who. int/ncds/governance/technical_annex.pdf

5. World Health Organization. Fiscal policies for diet and prevention of noncommunicable diseases: technical meeting report, 5-6 May 2015, Geneva, Switzerland [Internet]. Geneva: WHO; 2016 [cited 2019 Apr 20]. Available from: https://apps.who.int/iris/ handle/10665/250131

6. Woodward-Lopez G, Kao J, Ritchie L. To what extent have sweetened beverages contributed to the obesity epidemic?. Public Health Nutrition. 2011 Mar;14(3):499-509.

7. Brownell KD, Frieden TR. Ounces of prevention-the public policy case for taxes on sugared beverages. N Engl J Med. 2009 Apr 30;360(18):1805-8.

8. Malik VS, Pan A, Willett WC, Hu FB. Sugar-sweetened beverages and weight gain in children and adults: a systematic review and meta-analysis. Am J Clin Nutr. 2013 Oct 1;98(4):1084-102.

9. Xi B, Huang Y, Reilly KH, Li S, Zheng R, Barrio-Lopez MT, Martinez-Gonzalez MA, Zhou D. Sugar-sweetened beverages and risk of hypertension and CVD: a dose-response meta-analysis. Br J Nutr. 2015 Mar;113(5):709-17.

10. Imamura F, O'Connor L, Ye Z, Mursu J, Hayashino Y, Bhupathiraju $\mathrm{SN}$, et al. Consumption of sugar sweetened beverages, artificially sweetened beverages, and fruit juice and incidence of type 2 diabetes: systematic review, meta-analysis, and estimation of population attributable fraction. Br J Sports Med. 2016 Apr 1;50(8):496-504.

11. Singh GM, Micha R, Khatibzadeh S, Lim S, Ezzati M, Mozaffarian D. Estimated global, regional, and national disease burdens related to sugar-sweetened beverage consumption in 2010. Circulation. 2015 Aug 25;132(8):639-66.

12. Singh GM, Micha R, Khatibzadeh S, Shi P, Lim S, Andrews KG, et al. Global, regional, and national consumption of sugar-sweetened beverages, fruit juices, and milk: a systematic assessment of beverage intake in 187 countries. PLoS One. 2015 Aug 5;10(8):e0124845.

13. Legetic B, Medici A, Hernández-Avila M, Alleyne G, Hennis A, editors. Economic Dimensions of Noncommunicable Diseases in Latin America and the Caribbean. Disease Control Priorities, 3rd ed. [Internet]. Washington, DC: Pan American Health Organization; 2016 [cited 2019 Oct 17]. Available from: https://iris.paho.org/ handle/10665.2/28501

14. Colchero MA, Rivera-Dommarco J, Popkin BM, Ng SW. In Mexico, evidence of sustained consumer response two years after implementing a sugar-sweetened beverage tax. Health Aff (Millwood) 2017 Mar 1;36(3):564-71.

15. Caro JC, Corvalán C, Reyes M, Silva A, Popkin B, Taillie LS. Chile's 2014 sugar-sweetened beverage tax and changes in prices and purchases of sugar-sweetened beverages: An observational study in an urban environment. PLoS Medicine. 2018 Jul 3;15(7):e1002597.

16. Alvarado M, Unwin N, Sharp SJ, Hambleton I, Murphy MM, Samuels TA, et al. Assessing the impact of the Barbados sugar-sweetened beverage tax on beverage sales: an observational study. Int J Behav Nutr Phys Act. 2019 Jan 30;16(1):13.

17. Barrientos-Gutierrez T, Zepeda-Tello R, Rodrigues ER, Colchero-Aragonés A, Rojas-Martínez R, Lazcano-Ponce E, et al. Expected population weight and diabetes impact of the 1-peso-per-litre tax to sugar sweetened beverages in Mexico. PLoS One. 2017 May 17;12(5):e0176336.

18. World Health Organization. WHO technical manual on tobacco tax administration [Internet]. Geneva: WHO; 2010 [cited 2019 Feb 15] Available from: https:/ /apps.who.int/iris/handle/10665/44316

19. World Health Organization. Report on the global tobacco epidemic, 2017: monitoring tobacco use and prevention policies. Technical Note III: Tobacco taxes in WHO Member States [Internet]. Geneva: WHO; 2017 [cited 2019 Feb 15]. Available from: https:/ /apps.who. int/iris/handle/10665/255874 
20. World Health Organization. Health taxes: a primer (a WHO policy brief) [Internet]. Geneva: WHO; 2019 [cited 2020 Mar 23]. Available from: https://apps.who.int/iris/handle/10665/329757

21. Thow AM, Downs SM, Mayes C, Trevena H, Waqanivalu T, Cawley J. Fiscal policy to improve diets and prevent noncommunicable diseases: from recommendations to action. Bull World Health Org. 2018 Mar 1;96(3):201-10.

22. World Trade Organization. Trade Policy Review. Report by the Secretariat: Haiti. Revision. Trade Policy Review Body. WT/TPR/S/327/ Rev.1 [Internet]. Geneva: WTO; 2016 [cited 2020 Apr 15]. Available from: https://docs.wto.org/dol2fe/Pages/SS/directdoc.aspx?filename $=$ q: /WT $/$ TPR/S327R1.pdf

23. World Customs Organization. HS Nomenclature 2017 edition [Internet]. Brussels: WCO; 2017 [cited 2020 May 21]. Available from: http://www.wcoomd.org/en/topics/nomenclature/instrument -and-tools/hs-nomenclature-2017-edition/hs-nomenclature-2017 -edition.aspx

24. Sornpaisarn B, Shield KD, Österberg E, Rehm J. Resource tool on alcohol taxation and pricing policies [Internet]. Geneva: World
Health Organization; 2017 [cited 2019 Oct 17]. Available from: https://apps.who.int/iris/handle/10665/255795

25. Pan American Health Organization. Meeting to Develop a Standardized Tax Share Indicator for Alcoholic and Sugar-Sweetened Beverages (Washington, D.C., 24-25 July, 2018) [Internet]. Washington, DC: PAHO; 2019 [cited 2019 Nov 20]. Available from: http:// iris.paho.org/xmlui/handle/123456789/51715

26. Powell LM, Chriqui JF, Khan T, Wada R, Chaloupka FJ. Assessing the potential effectiveness of food and beverage taxes and subsidies for improving public health: a systematic review of prices, demand and body weight outcomes: Review of prices, demand and weight. Obes Rev. 2013 Feb;14(2):110-28.

Manuscript submitted on 12 October 2020. Revised version accepted for publication on 1 December 2020.

\section{Impuestos selectivos al consumo de bebidas azucaradas en América Latina y el Caribe}

RESUMEN Objetivo. Caracterizar el diseño de los impuestos selectivos al consumo de bebidas azucaradas en América Latina y el Caribe, y evaluar las oportunidades de aumentar su impacto en el consumo y la salud.

Métodos. Se llevó a cabo una búsqueda y una evaluación exhaustivas de legislaciones vigentes a marzo del 2019, recopilada mediante las herramientas de seguimiento ya existentes de la Organización Panamericana de la Salud y de la Organización Mundial de la Salud, fuentes secundarias, así como mediante una encuesta a ministerios de finanzas. El análisis se centró en el tipo de productos gravados y la estructura y la base de estos impuestos selectivos.

Resultados. De los 33 países evaluados, en 21 se aplican impuestos selectivos al consumo de bebidas azucaradas. En siete países también se aplican impuestos selectivos al consumo de agua embotellada y en al menos cuatro, se incluyen las bebidas lácteas azucaradas. Diez de estos impuestos selectivos al consumo son de tipo ad valorem con algunas bases imponibles fijadas al principio de la cadena de valor, siete son de tipo específico y cuatro son de estructura combinada o mixta. En tres países se aplican impuestos selectivos al consumo en función de la concentración de azúcares del producto.

Conclusiones. Si bien el número de países en que se aplican impuestos selectivos al consumo de bebidas azucaradas es prometedor, existe una gran heterogeneidad en su diseño en cuanto a la estructura, la base imponible y los productos gravados. Se podrían aprovechar aún más los impuestos selectivos existentes a fin de que tengan un mayor impacto sobre la salud y el consumo si se incluyen todas las categorías de bebidas azucaradas, excluyendo el agua embotellada, y recurriendo más a impuestos de tipo específico ajustados frecuentemente según la inflación y basados posiblemente en la concentración de azúcares del producto. Todos los países se beneficiarían si hubiera mayor orientación. Las próximas investigaciones deberían abordar esta brecha.

Palabras clave Enfermedades no transmisibles; política nutricional; economía de la salud; obesidad; legislación como asunto. 


\section{Imposto especial de consumo sobre bebidas açucaradas na América Latina e no Caribe}

RESUMO Objetivo. Caracterizar o modelo dos impostos especiais de consumo sobre bebidas açucaradas na América Latina e no Caribe e avaliar oportunidades para aumentar o impacto desses impostos no consumo de bebidas açucaradas e na saúde.

Métodos. Realizou-se uma pesquisa ampla e a análise de legislações vigentes em março de 2019, com informações obtidas por meio de instrumentos de monitoramento da Organização Pan-Americana da Saúde (OPAS) e da Organização Mundial da Saúde (OMS) já existentes, fontes secundárias e levantamento junto aos ministérios da Fazenda. A análise centrou-se no tipo de produtos tributados e na estrutura e base desses impostos especiais de consumo.

Resultados. Dos 33 países analisados, 21 aplicam impostos especiais de consumo sobre bebidas açucaradas. Em sete países os impostos especiais de consumo incidem também sobre água engarrafada e, em pelo menos quatro, incluem bebidas lácteas açucaradas. Dez desses tributos especiais são ad valorem com algumas bases tributárias estabelecidas no início da cadeia de valor, sete são de tipo específico e quatro têm uma estrutura combinada ou mista. Em três países os impostos especiais são estabelecidos com base na concentração de açúcares do produto.

Conclusões. Apesar do número promissor de países com impostos especiais de consumo sobre bebidas açucaradas, verifica-se grande heterogeneidade nos modelos de tributação em termos de estrutura, base tributária e produtos tributados. Os impostos especiais de consumo vigentes poderiam ser mais bem aproveitados para aumentar o impacto no consumo de bebidas açucaradas e na saúde: incluir todas as categorias de bebidas açucaradas, excluir água engarrafada e recorrer mais a impostos de tipo específico com a correção periódica pela inflação e, possivelmente, com base na concentração de açúcares do produto. Todos os países se beneficiariam em receber mais orientação. Pesquisas futuras devem ter como objetivo abordar essa lacuna.

Palavras-chave Doenças não transmissíveis; política nutricional; economia da saúde; obesidade; legislação como assunto. 